\title{
PENGARUH SOSIALISASI PERPAJAKAN TERHADAP KEPATUHAN WAJIB PAJAK DENGAN PENGETAHUAN PERPAJAKAN SEBAGAI VARIABEL INTERVENING (Studi Pada Wajib Pajak Orang Pribadi di KPP Pratama Kebumen)
}

\section{THE EFFECT OF TAX SOCIALIZATION ON TAXPAYER COMPLIANCE WITH KNOWLEDGE AS INTERVENING VARIABLE}

\author{
Dewi Kusuma Wardani \\ Erma Wati \\ Program Studi Akuntansi Fakultas Ekonomi Universitas Sarjanawiyata Tamansiswa \\ dewifeust@gmail.com
}

\begin{abstract}
Abtract: The Effect of Tax Socialization on Taxpayer Compliance with Knowledge as Intervening Variable

Taxes have a very important role in the Indonesian economy because taxes are a major source for the State of Indonesia to fund the State Budget (APBN). One of the factors that can be emphasized by the apparatus in raising tax awareness and compliance is by socializing the tax regulation either through counseling, moral appeals either with billboards media, billboards, or opening tax regulation sites that can be accessed by Taxpayers at any time.

This study aims to test the socialization of taxation on taxpayer compliance through taxation knowledge. To test the hypothesis, we use primary data with Convenience sampling method. Technique of data analysis using path analysis with tax socialization as variable $(X)$ and knowledge of taxation as intervening variable and taxpayer obedience as variable $(Y)$. After the data in the analysis, it was found that the socialization of taxes have a positive effect on tax knowledge has a $t$-value of 9.726 greater than the value of t-table 2.70 with a significant value of 0.000 . Knowledge of taxation have a positive effect on taxpayer compliance have value t-count 4,261 bigger than t-table value 2,70 with significant value 0,000 . Socialization of taxes have a positive effect on taxpayer compliance has a t-value of 5.744 is greater than the value of $t$-table 2.70 with a significant value of 0.000 . Variable of taxation socialization on taxpayer compliance equal to 0,502 and indirect influence equal to 0,4185. These results indicate that indirectly tax socialization has a significant effect on taxpayer compliance through taxation knowledge.
\end{abstract}

Keywords: Taxation Socialization, Tax Knowledge, Taxpayer Compliance.

\section{Abstrak: Pengaruh Sosialisasi Perpajakan terhadap Kepatuhan Wajib Pajak dengan Pengetahuan Perpajakan sebagai Variabel Intervening (Studi Pada Wajib Pajak Orang Pribadi di KPP Pratama Kebumen)}

Pajak memiliki peranan yang sangat penting dalam perekonomian Indonesia karena pajak merupakan sumber utama bagi Negara Indonesia untuk mendanai Anggaran Pendapatan dan Belanja Negara (APBN). Salah satu faktor yang bisa ditekankan oleh aparat dalam meningkatkan kesadaran dan kepatuhan pajak adalah dengan cara mensosialisasikan peraturan pajak baik itu melalui penyuluhan, seruan moral baik dengan media billboard, baliho, maupun membuka situs peraturan pajak yang setiap saat bisa diakses oleh Wajib Pajak.

Penelitian ini bertujuan untuk menguji pengeruh sosialisasi perpajakan terhadap kepatuhan wajib pajak melalui pengetahuan perpajakan. Untuk menguji hipotesis, digunakan data primer dengan metode Convenience sampling. Teknik analisis data menggunakan analisis jalur dengan sosialisasi perpajakan sebagai variabel $(\mathrm{X})$ serta pengetahuan perpajakan sebagai variabel intervening dan kepatuhan wajib pajak sebagai variable (Y). Setelah data di analisis, ditemukan bahwa sosialisasi perpajakan berpengaruh positif terhadap pengetahuan perpajakan memiliki nilai t-hitung 9,726 lebih besar dari nilai t-tabel 2,70 dengan nilai signifikan 0,000. Pengetahuan perpajakan berpengaruh positif terhadap kepatuhan wajib pajak memiliki nilai t-hitung 4,261 lebih besar dari nilai t-tabel 2,70 dengan nilai signifikan 0,000 . Sosialisasi perpajakan berpengaruh positif terhadap kepatuhan wajib pajak memiliki nilai t-hitung 5,744 lebih besar dari nilai t-tabel 2,70 dengan nilai signifikan 0,000. Variabel sosialisasi perpajakan terhadap kepatuhan wajib pajak sebesar 0,502 dan pengaruh tidak langsung sebesar 0,4185. 


\section{JURNAL NOMINAL / VOLUME VII NOMOR 1 / TAHUN 2018}

Hasil ini menunjukan bahwa secara tidak langsung sosialisasi perpajakan berpengaruh signifikan terhadap kepatuhan wajib pajak melalui pengetahuan perpajakan.

Kata Kunci: Sosialisasi Perpajakan, Pengetahuan Perpajakan, Kepatuhan Wajib Pajak.

\section{PENDAHULUAN}

Pajak merupakan pungutan negara yang tidak memberikan balas jasa secara langsung, sifatnya mengikat dan dapat dipaksakan, yang digunakan untuk kemakmuran rakyat (Wulandari dkk, 2014:94). Pajak memiliki dua fungsi utama, yaitu fungsi budgetair yang digunakan untuk membiayai seluruh pengeluaran rutin maupun pembangunan negara dan fungsi reguleren yang digunakan untuk mengatur kebijakan pemerintah dalam bidang sosial dan ekonomi (Wulandari,2014:94). Menurut Suyanto dkk (2016:9) pajak memiliki peranan yang sangat penting dalam perekonomian Indonesia karena pajak merupakan sumber utama bagi Negara Indonesia untuk mendanai Anggaran Pendapatan dan Belanja Negara (APBN).

Tabel 1 Presentase Penerimaan Pajak Pada APBN 2012-2016

(Dalam Milyar Rupiah)

\begin{tabular}{|c|c|c|c|c|c|}
\hline $\begin{array}{c}\text { Tahu } \\
\text { n }\end{array}$ & $\begin{array}{c}\text { Pendapa } \\
\text { tan } \\
\text { Pajak }\end{array}$ & $\begin{array}{c}\text { Buka } \\
\text { n } \\
\text { Pajak }\end{array}$ & $\begin{array}{c}\text { Hiba } \\
\text { h }\end{array}$ & Total & $\begin{array}{c}\% \\
\text { Paj } \\
\text { ak }\end{array}$ \\
\hline 2012 & 980.518 & $\begin{array}{c}351.80 \\
4\end{array}$ & 5.786 & $\begin{array}{c}1.338 .10 \\
9\end{array}$ & $73 \%$ \\
\hline 2013 & 1.077 .306 & $\begin{array}{c}354.75 \\
1\end{array}$ & 6.832 & $\begin{array}{c}1.438 .89 \\
1\end{array}$ & $75 \%$ \\
\hline 2014 & 1.146 .865 & $\begin{array}{c}398.59 \\
0\end{array}$ & 5.034 & $\begin{array}{c}1.550 .49 \\
0\end{array}$ & $74 \%$ \\
\hline 2015 & 1.240 .418 & $\begin{array}{c}255.62 \\
8\end{array}$ & $\begin{array}{c}11.97 \\
3\end{array}$ & $\begin{array}{c}1.508 .02 \\
0\end{array}$ & $82 \%$ \\
\hline 2016 & 1.539 .166 & $\begin{array}{c}245.08 \\
3\end{array}$ & 1.975 & $\begin{array}{c}1.786 .22 \\
5\end{array}$ & $86 \%$ \\
\hline
\end{tabular}

Sumber: bps.go.id data diolah tahun 2017
Pada tabel 1.1 menunjukkan bahwa sumber utama dari penerimaan Negara Indonesia terletak pada sektor pajak. Setiap tahun, nominal pendapatan pajak selalu mengalami peningkatan. Dilihat dari nilai persentasenya, pendapatan pajak selalu menduduki persentase di atas $70 \%$. Dengan angka yang sedemikian tinggi, maka penerimaan pajak memegang peranan yang sangatlah penting dalam roda perekonomian Indonesia (Jannah, 2016:1).

Salah satu dasar penerimaan pajak sesuai target adalah kepatuhan wajib pajak. Kepatuhan Wajib Pajak adalah kondisi dimana Wajib Pajak memenuhi kewajiban perpajakan dan melaksanakan hak perpajakan (Rohmawati dkk, 2012:5). Kepatuhan wajib pajak yang baik akan dapat dilihat dari keteraturannya untuk menyetorkan pajak (Fatimah dan Wardani, 2017:4). Widyowati (2015:7) menyatakan dengan adanya kepatuhan dari wajib pajak diharapkan wajib pajak berusaha untuk memenuhi peraturan hukum perpajakan yang berlaku, baik memenuhi kewajiban ataupun melaksanakan hak perpajakannya. Keuntungan kepatuhan wajib pajak antara lain kepatuhan dalam mendaftarkan diri, tepat waktu dalam menyampaikan SPT untuk semua jenis pajak, menghitung dan 


\section{JURNAL NOMINAL / VOLUME VII NOMOR 1 / TAHUN 2018}

membayar pajak terutang serta membayar tunggakan pajak (Winerungan, 2013:964).

Tabel 2 Data Penerimaan dan Kepatuhan Wajib Pajak di KPP Pratama Kab. Kebumen Periode 2012-2016

\begin{tabular}{|c|c|c|c|c|}
\hline $\begin{array}{c}\text { Tahu } \\
\text { n }\end{array}$ & $\begin{array}{c}\text { Juml } \\
\text { ah } \\
\text { Waji } \\
\text { b } \\
\text { Paja } \\
\text { k }\end{array}$ & $\begin{array}{c}\text { WP } \\
\text { Wajib } \\
\text { SPT } \\
\text { Tahunan }\end{array}$ & $\begin{array}{c}\text { Laporan } \\
\text { SPT } \\
\text { Tahunan }\end{array}$ & $\begin{array}{c}\% \\
\text { Ketida } \\
\text { kpatu } \\
\text { han }\end{array}$ \\
\hline 2012 & $\begin{array}{c}10.34 \\
4\end{array}$ & 56.768 & 47.147 & $17 \%$ \\
\hline 2013 & $\begin{array}{c}13.70 \\
4 \\
\end{array}$ & 58.089 & 49.435 & $27 \%$ \\
\hline 2014 & $\begin{array}{c}16.92 \\
2\end{array}$ & 78.700 & 54.565 & $31 \%$ \\
\hline 2015 & $\begin{array}{c}13.13 \\
7 \\
\end{array}$ & 77.394 & 56.196 & $27 \%$ \\
\hline 2016 & $\begin{array}{c}14.67 \\
4 \\
\end{array}$ & 95.208 & 61.343 & $36 \%$ \\
\hline
\end{tabular}

Sumber : KPP Pratama Kebumen, 2017

Pada tabel 1.2 dapat kita ketahui bahwa dari tahun 2012-2016 jumlah wajib pajak orang pribadi di KPP Pratama Kebumen mengalami peningkatan, akan tetapi dengan meningkatnya wajib pajak orang pribadi terdaftar, belum diikuti dengan kepatuhan wajib pajak orang pribadi yang menyampaikan SPT Tahunan dan presentase ketidak patuhan wajib pajak terus mengalami kenaikan. Kenaikan presentase ketidak patuhan wajib pajak orang pribadi di kebumen ini dikarenakan adanya ketidakpatuhan wajib pajak.

Ketidakpatuhan wajib pajak ini dipengaruhi oleh beberapa faktor, diantaranya adalah kurangnya kualitas pelayanan, sistem pelayanan yang belum memuaskan, kurangnya kesadaran dan kepedulian wajib pajak untuk memenuhi kewajiban perpajakannya yang sesuai dengan peraturan perpajakannya (Setiawan, 2016:81). Hal inilah yang nantinya akan menimbulkan pelanggaran peraturan perundangan-undangan pajak dengan cara penghindaran pajak. Dari ketidakpatuhan inilah yang nantinya harus diperbaiki dengan beberapa cara. Salah satu upaya yang telah dilakukan oleh Kantor Pelayanan Pajak Pratama Kebumen dalam meningkatkan jumlah wajib pajak di Kebumen yaitu dengan mengadakan penyuluhan kepada masyarakat dengan tujuan menyadarkan masyarakat akan kewajiban perpajakannya, mengadakan pelayanan tentang konsultasi perpajakan, melalui media cetak serta dengan mengadakan kampanye dan pembagian souvenir kepada wajib pajak (Setiawan, 2016:74-76). Sosialisasi ini nantinya akan meningkatkan kepatuhan wajib pajak, karena menambah pengetahuan dan kesadaran wajib pajak dalam melakukan pembayaran pajak.

Kepatuhan Wajib Pajak dapat dipengaruhi oleh beberapa faktor, baik faktor eksternal maupun faktor internal. Salah satu faktor eksternal yang dapat mempengaruhi kepatuhan wajib pajak orang pribadi adalah sosialisasi perpajakan, sedangkan faktor internalnya adalah pengetahuan perpajakan. Dalam penelitian ini, sosialisasi perpajakan menjadi variabel independen dan pengetahuan perpajakan menjadi variabel intervening karena sosialisasi perpajakan dan pengetahuan 


\section{JURNAL NOMINAL / VOLUME VII NOMOR 1 / TAHUN 2018}

perpajakan adalah dua hal yang berbeda yang secara tidak langsung mempunyai hubungan (Anwar, 2015:6). Pengetahuan perpajakan bisa menjadi intervening bagi sosialisasi perpajakan dalam mempengaruhi kepatuhan wajib pajak orang pribadi.

\section{Menurut Sudrajat $\quad(2015: 194)$} sosialisasi perpajakan berarti suatu upaya yang dilakukan untuk memberikan informasi mengenai perpajakan yang bertujuan agar seseorang ataupun kelompok paham tentang perpajakan sehingga kepatuhan wajib pajak akan meningkat. Jika wajib pajak diberikan pemahaman yang baik dan benar melalui sosialisasi, maka wajib pajak akan memiliki pengetahuan tentang pentingnya membayar pajak. Hal ini didukung oleh penelitian Jannah (2016:46) menemukan sosialisasi pajak yang intensif dapat meningkatkan pengetahuan calon wajib pajak mengenai semua hal yang berkaitan dengan perpajakan. Penelitian Anwar (2015:53) menyatakan sosialisasi perpajakan berpengaruh signifikan terhadap pengetahuan perpajakan wajib pajak. Tanpa adanya sosialisasi yang efektif kepada wajib pajak, maka wajib pajak akan mengalami kesulitan dalam memenuhi kewajiban perpajakannya. Berbeda dengan penelitian Winerungan (2013: 967) bahwa dengan kurang intensifnya sosialisasi yang diberikan akan berdampak pada rendahnya pengetahuan dan pemahaman wajib pajak sehingga berpengaruh pada kepatuhan pajaknya.

Pengetahuan perpajakan adalah proses pengubah sikap dan tata laku wajib pajak atau kelompok wajib pajak dalam usaha mendewasakan manusia melalui upaya pelatihan (Anwar, 2015:17). Adanya pengetahuan perpajakan yang baik dapat membantu meningkatkan kepatuhan wajib pajak akan pentingnya membayar pajak dan wajib pajak dapat melakukannya sesuai dengan aturan perundang-undangan perpajakan. Jika wajib pajak tidak memiliki pengetahuan mengenai peraturan dan proses perpajakan, maka wajib pajak tidak dapat menentukan perilakunya dengan tepat (Tabun, 2016:28). Hal ini didukung oleh penelitian Witono (2008:206) yang menyatakan terdapat pengaruh yang signifikan pengetahuan pajak terhadap tingkat kepatuhan wajib pajak dan penelitian Tambun (2016:36) yang menyatakan bahwa pengetahuan wajib pajak berpengaruh signifikan terhadap kepatuhan wajib pajak. Berbeda dengan penelitian Hardiningsih dkk (2011:138) yang menyatakan pengetahuan peraturan perpajakan tidak berpengaruh terhadap kemauan membayar pajak dan Susanto (2013:12) yang menyatakan bahwa persepsi pengetahuan wajib pajak tidak mempengaruhi kepatuhan. 


\section{JURNAL NOMINAL / VOLUME VII NOMOR 1 / TAHUN 2018}

Semakin tinggi intensitas sosialisasi perpajakan yang dilakukan, maka akan semakin tinggi tingkat kepatuhan wajib pajak orang pribadi. Dengan adanya sosialisasi pajak berarti wajib pajak akan lebih mengetahui mengenai arti pentingnya membayar pajak sehingga pengetahuan wajib pajak orang pribadi akan bertambah serta dapat melaksanakan kewajiban dan hak perpajakannya. Dengan demikian, sosialisasi perpajakan sangat berpengaruh terhadap kepatuhan wajib pajak orang pribadi. Hal ini didukung penelitian Rohmawati dkk (2012:12) yang menyatakan sosialisasi berpengaruh positif terhadap kepatuhan Wajib Pajak, penelitian Widowati (2015: 11) yang menyatakan sosialisasi perpajakan berpengaruh terhadap kepatuhan wajib pajak orang pribadi dan penelitian Purba (2016:29) yang menyatakan bahwa terdapat pengaruh positif antara sosialisasi perpajakan terhadap kepatuhan wajib pajak orang pribadi. Berbeda dengan penelitian Winerungan (2013:969) yang menyatakan sosialisasi perpajakan tidak memiliki pengaruh terhadap kepatuhan wajib pajak orang pribadi dan Primasari (2016:197) yang menyatakan bahwa sosialisasi perpajakan tidak berpengaruh terhadap kepatuhan Wajib Pajak.

Sosialisasi perpajakan dilakukan untuk memberikan informasi yang baik dan benar sehingga wajib pajak akan memiliki pengetahuan tentang arti pentingnya membayar pajak dan pada akhirnya akan meningkatkan kepatuhan wajib pajak orang pribadi. Jika sosialisasi perpajakan disampaikan dengan jelas, benar, dan nyaman oleh petugas pajak maka wajib pajak akan memiliki pengetahuan tentang arti pentingnya membayar pajak yang secara otomatis akan meningkatkan kepatuhan wajib pajak. Hal ini didukung oleh penelitian Anwar (2015:53) menemukan sosialisasi perpajakan berpengaruh signifikan terhadap pengetahuan perpajakan wajib pajak. Penelitian Purba (2016:29) menemukan bahwa terdapat pengaruh positif antara sosialisasi perpajakan terhadap kepatuhan wajib pajak orang pribadi. Penelitian Witono (2008:206) menyatakan terdapat pengaruh yang signifikan pengetahuan pajak terhadap tingkat kepatuhan wajib pajak.

Berdasarkan uraian diatas, penelitian tentang pengaruh sosialisasi perpajakan dalam meningkatkan kepatuhan perpajakan dengan menjadikan pengetahuan perpajakan sebagai intervening pengaruh tersebut sangat penting untuk dianalisis. Hal tersebut menjadi alasan penulis untuk melakukan penelitian skripsi dengan mengambil judul "Pengaruh Sosialisasi Perpajakan Terhadap Kepatuhan Wajib Pajak Dengan Pengetahuan Perpajakan Sebagai Variabel Intervening (Studi Pada Wajib Pajak Orang Pribadi di KPP Pratama Kebumen". Perbedaan penelitian 


\section{JURNAL NOMINAL / VOLUME VII NOMOR 1 / TAHUN 2018}

ini dengan penelitian terdahulu yang dilakukan oleh Puspita (2016:8) dengan judul analisis jalur pengaruh sosialisasi terhadap kepatuhan wajib Pajak Bumi dan Bangunan Kota Kediri dengan kesadaran sebagai variabel intervening. Variabel dependen dalam penelitian ini merupakan kepatuhan wajib pajak orang pribadi dan penggunaan pengetahuan perpajakan sebagai variabel yang mengintervening sosialisasi perpajakan untuk meningkatkan kepatuhan wajib pajak.

\section{LANDASAN TEORI DAN PENGEMBANGAN HIPOTESIS}

Menurut pasal 1 Undang-Undang Nomor 16 tahun 2009 tentang KUP berbunyi: "Pajak adalah konstribusi wajib kepada negara yang terutang oleh orang pribadi atau badan yang bersifat memaksa berdasarkan Undang-Undang, dengan tidak mendapat imbalan secara langsung dan digunakan untuk keperluan negara bagi sebesar-besarnya kemakmuran rakyat". Pajak merupakan sumber penerimaan Negara terbesar sehingga berbagai cara untuk mensukseskan pendapatan dari sektor pajak dilakukan oleh pemerintah (Suyanto dkk, 2016:10).

Pajak memiliki dua fungsi utama, yaitu fungsi budgetair yang digunakan untuk membiayai seluruh pengeluaran rutin maupun pembangunan negara dan fungsi reguleren yang digunakan untuk mengatur kebijakan pemerintah dalam bidang sosial dan ekonomi (Wulandari,2014:94). Membayar pajak bukan hanya sebuah kewajiban, tetapi juga hak dan kewajiban bagi setiap warga negara untuk ikut berpartisipasi melalui pembiayaan negara sehingga dapat meningkatkan kemakmuran negara.

$$
\text { Winerungan }
$$

berpendapat sosialisasi adalah programprogram yang dilakukan oleh Direktorat Jendral Pajak untuk meningkatkan pemahaman dan pengetahuan masyarakat. Selain itu,dengan dilakukannya sosialisasi tentang pajak, diharapkan dapat membuat wajib pajak mengetahui, memahami, dan menyadari pentingnya pajak bagi pembangunan (Puspita, 2016:3). Kurangnya sosialisasi mungkin berdampak pada rendahnya pengetahuan masyarakat tentang pajak yang menyebabkan rendahnya kesadaran masyarakat untuk melaporkan dan membayar pajak yang pada akhirnya mungkin menyebabkan rendahnya tingkat kepatuhan Wajib Pajak (Winerungan, 2013:963). Sosialisasi perpajakan berfungsi meningkatkan pengetahuan perpajakan Wajib Pajak, terutama Wajib Pajak Orang Pribadi. Dengan demikian sudah menjadi tanggung jawab petugas pajak untuk melakukan sosialisasi perpajakan.

Pengetahuan Perpajakan ialah keadaan wajib pajak dalam memiliki 


\section{JURNAL NOMINAL / VOLUME VII NOMOR 1 / TAHUN 2018}

pengetahuan mengenai ketentuan umum dan tata cara perpajakan, sistem perpajakan, dan fungsi pajak (Khasanah, 2014:40). Pengetahuan tentang peraturan pajak sangat penting untuk menumbuhkan perilaku patuh (Rahayu, 2017:19). Suderajat (2015:197) mengatakan pengetahuan tentang peraturan perpajakan akan mempengaruhi sikap Wajib Pajak terhadap kewajiban pajak. Pengetahuan perpajakan mempunyai peran penting dalam meningkatkan kepatuhan perpajakan. Ketika Wajib Pajak mengetahui dari fungsi pajak, maka Wajib Pajak akan mengetahui pentingnya membayar pajak, sehingga dapat meningkatkan kepatuhan Wajib Pajak. Apabila tingkat kepatuhan Wajib Pajak tinggi, tentunya penerimaan Negara dari sektor pajak akan terus meningkat dan pemerintah dapat menjalankan perannya (Wardani dan Asis, 2017:2). Indikator dari pengetahuan perpajakan menurut Khasanah (2014:46) terdiri dari pengetahuan mengenai ketentuan umum dan tata cara perpajakan, pengetahuan mengenai fungsi pembayaran, dan pengetahuan mengenai sistem perpajakan di Indonesia. Dengan adanya pengetahuan yang benar mengenai pajak, diharapkan dapat meningkatkan kepatuhan Wajib Pajak untuk melaksanakan kewajiban sebagai warga negara dengan membayar pajak tepat waktu (Wulandari dkk, 2014:95).

\section{Pengaruh Sosialisasi Perpajakan}

\section{Terhadap Pengetahuan Perpajakan}

Sosialisasi adalah suatu konsep umum yang dimaknakan sebagai proses belajar melalui interaksi dengan orang lain, tentang cara berfikir, merasakan dan bertindak dimana kesemuanya itu merupakan hal-hal yang sangat penting dalam menghasilkan partisipasi sosial yang efektif (Wurianti dkk, 2015:6). Pengetahuan wajib pajak tentang pajak adalah proses pengubahan sikap dan tata laku seorang atau kelompok wajib pajak dalam usaha mendewasakan manusia melalui upaya pengajaran dan pelatihan melalui sosialisasi. Menurut Jannah (2016:46) melalui sosialisasi pajak yang intensif dapat meningkatkan pengetahuan calon wajib pajak mengenai semua hal yang berkaitan dengan perpajakan. Tanpa adanya sosialisasi yang efektif kepada wajib pajak maka wajib pajak akan mengalami kesulitan dalam memenuhi kewajiban perpajakannya. Untuk dapat memenuhi kewajiban perpajakan, Wajib Pajak dituntut untuk mengerti atau paham terhadap pengetahuan perpajakan yang telah disosialisasikan yang diharapkan dapat meningkatkan kepatuhan Wajib Pajak (Rohmawati dkk, 2012:4).

Kurangnya pengetahuan dan wawasan karena rendahnya sosialisasi perpajakan akan menyebabkan mereka tidak memahami bagaimana caranya melaksanakan kewajiban perpajakan dan 


\section{JURNAL NOMINAL / VOLUME VII NOMOR 1 / TAHUN 2018}

pada akhirnya tidak melaksanakan kewajiban perpajakannya, dan hal tersebut berdampak pada penerimaan pajak negara. Jika pemerintah berhasil dalam menjalankan sosialisasi perpajakan, maka masyarakat akan lebih memahami pengetahuan perpajakan dan kepatuhan wajib pajak juga meningkat. Hal ini didukung dengan penelitian Widyowati (2013:8).

Penelitian yang dilakukan oleh Anwar (2015:53) menemukan bahwa sosialisasi perpajakan berpengaruh positif terhadap pengetahuan perpajakan wajib pajak. Sosialisasi perpajakan membantu meningkatkan pengetahuan para Wajib Pajak tentang pentingnya membayar pajak sehingga menyebabkan wajib pajak tersebut patuh. Proses sosialisasi perpajakan diharapkan berdampak pada pengetahuan perpajakan masyarakat secara positif sehingga dapat juga meningkatkan jumlah Wajib Pajak, meningkatkan kepatuhan Wajib Pajak, yang pada akhirnya meningkatkan penerimaan negara dari sektor pajak (Prabowo, 2015:1065). Jadi peneliti mengambil hipotesis yaitu:

H1: Sosialisasi perpajakan berpengaruh positif terhadap pengetahuan perpajakan.

Pengaruh Pengetahuan Perpajakan Terhadap Kepatuhan Wajib Pajak

Pengetahuan perpajakan digunakan oleh wajib pajak sebagai informasi pajak dalam melakukan tindakan perpajakan. Menurut Rohmawati dkk (2012:12), semakin tinggi pengetahuan dan pemahaman wajib pajak maka wajib pajak dapat menentukan perilakunya dengan lebih baik dan sesuai dengan ketentuan perpajakan, yaitu menjadi lebih patuh.

Witono (2008:196) menganalisa peran pengetahuan pajak pada kepatuhan wajib pajak. Hasil penelitian ini menunjukkan bahwa terdapat pengaruh positif pengetahuan pajak terhadap tingkat kepatuhan wajib pajak. Adanya pengetahuan perpajakan yang baik dapat membantu meningkatkan kepatuhan wajib pajak akan pentingnya membayar pajak dan wajib pajak dapat melakukannya sesuai dengan aturan perundang-undangan perpajakan. Jika wajib pajak tidak memiliki pengetahuan mengenai peraturan dan proses perpajakan, maka wajib pajak tidak dapat menentukan perilakunya dengan tepat. Hal ini didukung dengan penelitian Tambun (2016:36), yang menyatakan pengetahuan wajib pajak berpengaruh positif terhadap kepatuhan wajib pajak. Jadi, peneliti mengambil hipotesis yaitu:

H2: Pengetahuan perpajakan berpengaruh positif terhadap kepatuhan Wajib Pajak.

Pengaruh Sosialisasi Perpajakan Terhadap Kepatuhan Wajib Pajak

Sosialisasi merupakan hal yang penting dalam upaya peningkatan 


\section{JURNAL NOMINAL / VOLUME VII NOMOR 1 / TAHUN 2018}

kesadaran dan kepatuhan wajib pajak. Sosialisasi perpajakan adalah pemberian wawasan dan pembinaan kepada wajib pajak agar mengetahui tentang segala hal mengenai perpajakan (Tambun, 2016:29).

Direktorat Jenderal Pajak selalu berupaya mengoptimalkan pelayanannya supaya Wajib Pajak selalu melaksanakan kewajibannya. Salah satu cara mengoptimalkan pelayanan tersebut adalah dengan mensosialisasikan pentingnya membayar pajak yang diharapkan dapat meningkatkan kepatuhan kepada Wajib Pajak untuk memenuhi kewajiban perpajakannya.

Salah satu faktor yang bisa ditekankan oleh aparat dalam meningkatkan kesadaran dan kepatuhan pajak adalah dengan cara mensosialisasikan peraturan pajak baik itu melalui penyuluhan, seruan moral baik dengan media billboard, baliho, maupun membuka situs peraturan pajak yang setiap saat bisa diakses oleh Wajib Pajak (Witono, 2008:197). Sosialisasi pajak berpengaruh positif dan signifikan terhadap kepatuhan wajib pajak (Suderajat dkk, 2015:193).

Semakin meningkatnya kegiatan sosialiasi maka tingkat kepatuhan wajib pajak akan meningkat pula. Hal ini didukung dengan penelitian Rohmawati dkk (2012:11) yang menyatakan . sosialisasi berpengaruh positif terhadap kepatuhan Wajib Pajak, penelitian Widowati (2015: 11) yang menyatakan sosialisasi perpajakan berpengaruh terhadap kepatuhan wajib pajak orang pribadi, dan penelitian Purba (2016:29) yang menyatakan bahwa terdapat pengaruh positif antara sosialisasi perpajakan terhadap kepatuhan wajib pajak orang pribadi. Jadi, peneliti mengambil hipotesis yaitu:

\section{H3: Sosialisasi perpajakan berpengaruh} positif terhadap kepatuhan Wajib Pajak. Pengaruh Sosialisasi Perpajakan Pada Kepatuhan Wajib Pajak Dengan Pengetahuan Perpajakan Sebagai Variabel Intervening

Variabel intervening yang digunakan dalam penelitian ini adalah pengetahuan perpajakan karena sosialisasi perpajakan dan pengetahuan perpajakan adalah dua hal yang berbeda yang secara tidak langsung mempunyai hubungan (Anwar, 2015:6). Pengetahuan perpajakan bisa menjadi intervening bagi sosialisasi perpajakan dalam mempengaruhi kepatuhan Wajib Pajak. Semakin tinggi tingkat sosialisasi perpajakan maka semakintinggi tingkat pengetahuan perpajakan, dan semakin tinggi tingkat pengetahuan perpajakan maka akan semakin tinggi tingkat kepatuhan wajib pajak orang pribadi.

Sosialisasi perpajakan dilakukan untuk memberikan informasi yang baik dan benar sehingga wajib pajak akan memiliki pengetahuan tentang arti pentingnya membayar pajak dan pada akhirnya akan meningkatkan kepatuhan wajib pajak orang 


\section{JURNAL NOMINAL / VOLUME VII NOMOR 1 / TAHUN 2018}

pribadi. Jika sosialisasi perpajakan disampaikan dengan jelas, benar, dan nyaman oleh petugas pajak maka wajib pajak akan memiliki pengetahuan tentang arti pentingnya membayar pajak yang secara otomatis akan meningkatkan kepatuhan wajib pajak. Hal ini didukung oleh penelitian Anwar (2015:53) yang menyatakan sosialisasi perpajakan berpengaruh positif terhadap pengetahuan perpajakan wajib pajak. Penelitian Purba (2016:29) menemukan bahwa terdapat pengaruh positif antara sosialisasi perpajakan terhadap kepatuhan wajib pajak orang pribadi. Penelitian Witono (2008:206) menyatakan terdapat pengaruh positif pengetahuan pajak terhadap tingkat kepatuhan wajib pajak. Jadi, peneliti mengambil hipotesis yaitu:

H4: Sosialisasi perpajakan berpengaruh positif terhadap kepatuhan Wajib Pajak dengan pengetahuan perpajakan sebagai variabel intervening.

\section{METODE PENELITIAN}

Populasi, Sample dan Teknik Pengmbilan Sampel

Menurut Kuncoro (2003:103) populasi adalah kelompok elemen yang lengkap dimana kita tertarik untuk mempelajarinya atau menjadi objek penelitian. Populasi dalam penelitian ini adalah Wajib Pajak orang pribadi yang terdaftar di KPP Pratama Kebumen.
Sampel adalah suatu himpunan bagian dari unit populasi (Kuncoro, 2003:103). Penentuan sampel penelitian ini menggunakan convenience sampling. Convenience sampling adalah teknik pengambilan sampel yang mudah ditemui oleh peneliti (Sekaran: 2003:24). Sampel penelitian ini adalah 100 orang Wajib Pajak orang pribadi yang terdaftar di KPP Pratama Kebumen. Sampel diperoleh dari penyebaran kuesioner ke Wajib Pajak orang pribadi yang datang ke KPP Pratama Kebumen.

\section{Pengembangan Instrumen Penelitian}

Instrumen yang digunakan dalam penelitian ini adalahinstrumen kuesioner untuk variabel kepatuhan wajib pajak, pengetahuan perpajakan dan variabel sosialisasi perpajakan. Penelitian ini menggunakan pilot test atau uji awal penelitian sebelum penelitian sesungguhnya. Menurut Wulandari dkk (2014:97), tujuan pilot test yaitu untuk meyakinkan item kuesioner telah mencukupi dan benar menurut responden.

Pilot test pada penelitianini dilakukan dengan menyebar kuesioner sebanyak 30 responden kepada mahasiswa di Universitas Sarjanawiyata Tamansiswa semester lima (5) yang sudah mendapat materi mengenai perpajakan.

Pada penelitian ini, variabel ini akan diukur dengan likert scale 5 point mulai dari sangat tidak setuju, tidak setuju, netral, 


\section{JURNAL NOMINAL / VOLUME VII NOMOR 1 / TAHUN 2018}

setuju, dan sangat setuju. Berikut ringkasan

definisi operasional kepatuhan wajib pajak, sosialisasi perpajakan dan pengetahuan perpajakan:

\section{Kepatuhan Wajib Pajak (Y)}

Kepatuhan Wajib Pajak adalah kondisi dimana Wajib Pajak memenuhi kewajiban perpajakan dan melaksanakan hak perpajakan, Rohmawati dkk, (2012:5).

\begin{tabular}{|c|c|}
\hline Indikator & Item Pertanyaan \\
\hline $\begin{array}{l}\text { 1. Mendaftar. } \\
\text { (Khasanah, } \\
\text { 2014:62) }\end{array}$ & $\begin{array}{l}\text { 1. Saya mendaftarkan NPWP atas } \\
\text { kemauan sendiri. } \\
\text { 2. Setiap wajib pajak harus } \\
\text { mendaftarkan diriuntuk NPWP. }\end{array}$ \\
\hline $\begin{array}{l}\text { Menghitung. } \\
\text { (Khasanah, } \\
\text { 2014:62) }\end{array}$ & $\begin{array}{l}\text { 3. Saya selalu menghitung } \\
\text { kewajiban angsuran pajak } \\
\text { penghasilan saya. } \\
\text { 4. Saya selalu menghitung pajak } \\
\text { yang terutang dengan benar. } \\
\text { 5. Saya mampu melakukan } \\
\text { perhitungan pajak dengan benar. }\end{array}$ \\
\hline $\begin{array}{l}\text { 3. Membayar. } \\
\text { (Nurhidayah, } \\
\text { 2015:13) }\end{array}$ & $\begin{array}{l}\text { 6. Saya selalu membayar } \\
\text { kekurangan pajak yang ada } \\
\text { sebelum dilakukan pemeriksaan. } \\
\text { 7. Saya selalu tepat waktu dalam } \\
\text { membayar pajak. } \\
\text { 8. Saya bersedia membayar } \\
\text { kewajiban pajak sayabeserta } \\
\text { tunggakan pajaknya. } \\
\text { 9. } \begin{array}{l}\text { Banyaknya tempat pembayaran } \\
\text { dapat mempermudah wajib pajak }\end{array} \\
\text { untuk membayar tepat waktu. } \\
\text { 10. Saya selalu membayar kewajiban } \\
\text { angsuran pajak penghasilan saya. } \\
\text { 11. Saya tidak pernah membayar } \\
\text { kewajiban angsuran pajak } \\
\text { penghasilan saya* }\end{array}$ \\
\hline
\end{tabular}

4. Melaporkan (Winerungan, 2013:964:965)
12. Saya selalu tepat waktu dalam melaporkan SPT untuk semua jenis pajak dalam dua tahun terakhir.

13. Saya selalu melaporkan dan menyampaikan SPT ke Kantor Pajak tepat waktu sebelum batas terakhir.

14. Saya telah mengetahui batas akhir dalampelaporan pajak.

\section{Sosialisasi Perpajakan (X1)}

Sosialisasi perpajakan adalah program-program yang dilakukan oleh Direktorat Jendral Pajak untuk meningkatkan pemahaman dan pengetahuan masyarakat, Winerungan (2013:963).

\begin{tabular}{|c|c|}
\hline Indikator & Item Pernyataan \\
\hline $\begin{array}{l}\text { 1. Penyelenggaraan } \\
\text { sosialisasi. } \\
\text { (Jannah, } \\
\mathbf{2 0 1 6 : 5 3 )}\end{array}$ & 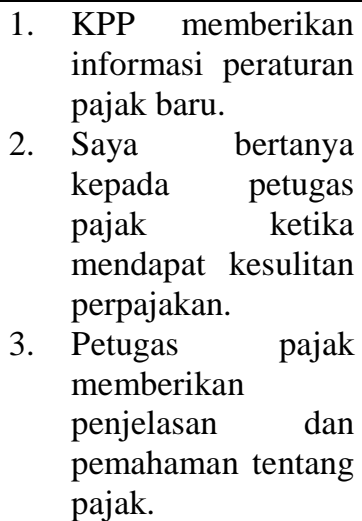 \\
\hline $\begin{array}{l}\text { 2. Media sosialisasi. } \\
\text { (Jannah, } \\
\text { 2016:53) }\end{array}$ & 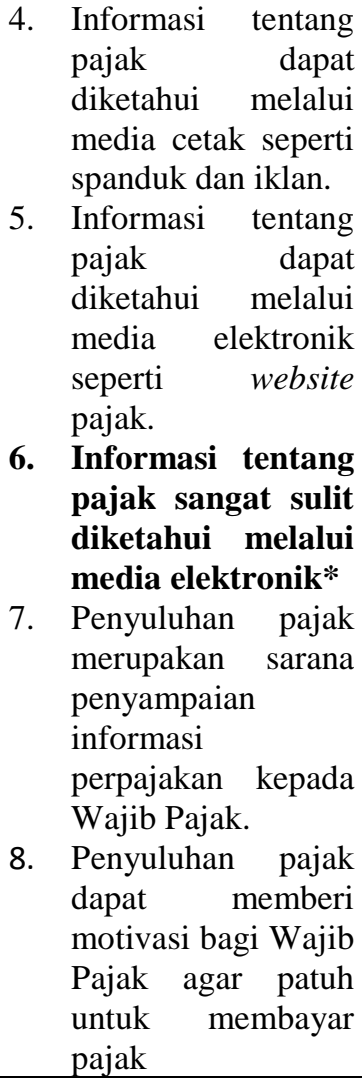 \\
\hline
\end{tabular}


JURNAL NOMINAL / VOLUME VII NOMOR 1 / TAHUN 2018

\begin{tabular}{lll}
\hline $\begin{array}{l}\text { Manfaat } \\
\text { sosialisasi. } \\
\text { (Jannah, }\end{array}$ & 9. & $\begin{array}{l}\text { Sosialisasi pajak } \\
\text { dapat memberikan } \\
\text { 2016:53) }\end{array}$ \\
& penjelasan pajak \\
kepada Wajib Pajak. & 10. \\
& Sosialisasi pajak \\
& pengertian memberikan \\
& pentingnya pajak \\
& kepada Wajib Pajak. \\
11. & Sosialisasi pajak \\
& membuat Wajib \\
& Pajak melaksanakan \\
& tindakan sesuai \\
& dengan ketentuan \\
peraturan & perpajakan.
\end{tabular}

\section{Pengetahuan Perpajakan (X2)}

Pengetahuan Perpajakan ialah keadaan wajib pajak dalam memiliki pengetahuan mengenai ketentuan umum dan tata cara perpajakan, sistem perpajakan, dan fungsi pajak, Khasanah, (2014:40).

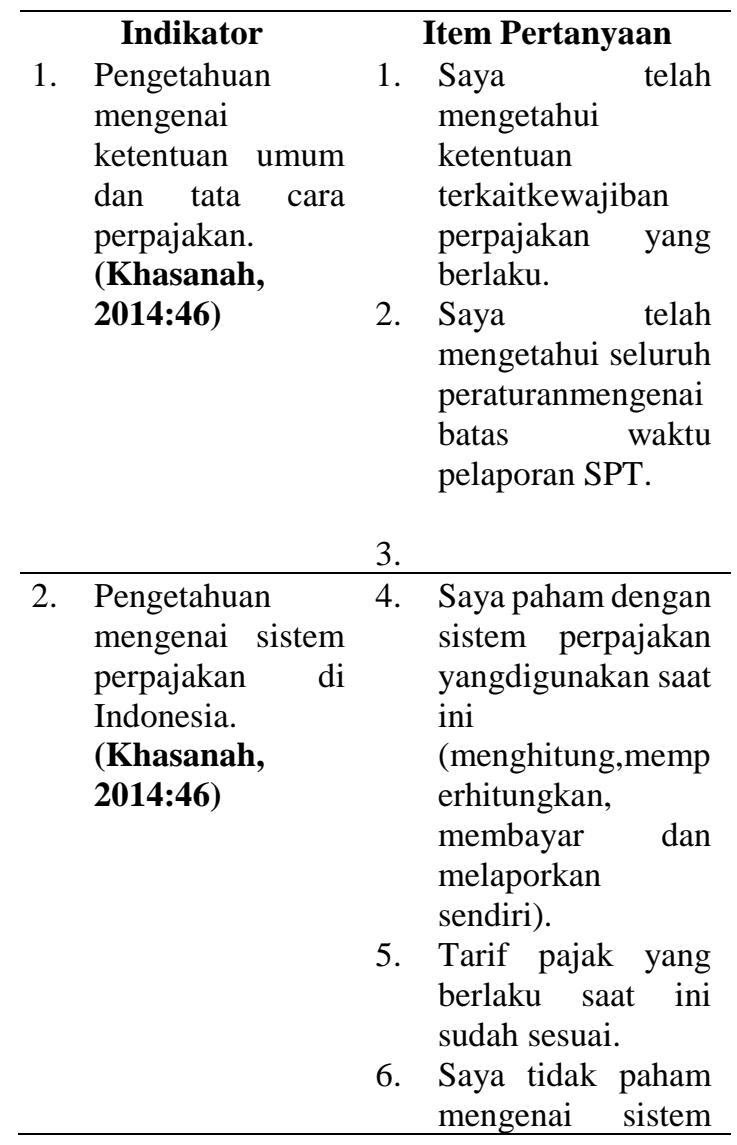

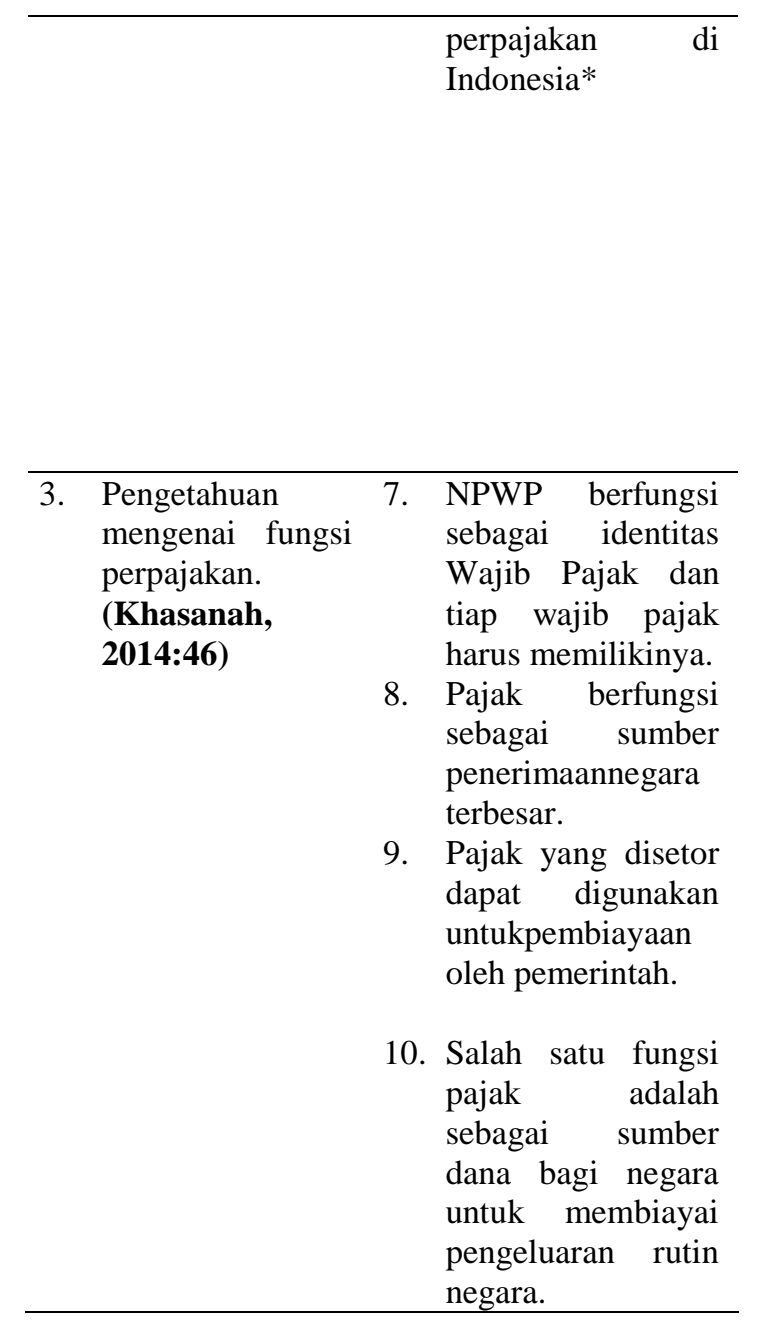

\section{Metode Analisis Data}

Teknik analisis data yang digunakan pada penelitian ini adalah menggunakan analisis jalur dengan bantuan software SPSS. Menurut Puspita (2016:4) teknik analisis data menggunakan analisis jalur untuk mengetahui pengaruh langsung variabel $\mathrm{X}$ terhadap variabel $\mathrm{Y}$, dan pengaruh tidak langsung, yaitu pengaruh variabel $\mathrm{X}$ terhadap variabel $\mathrm{Y}$ melalui variabel $\mathrm{Z}$. 
JURNAL NOMINAL / VOLUME VII NOMOR 1 / TAHUN 2018

HASIL DAN PEMBAHASAN

Statistik Deskriptif

\begin{tabular}{|c|c|c|c|c|c|}
\hline & $\mathbf{N}$ & Min & $\operatorname{Max}$ & Mean & $\begin{array}{l}\text { Std. } \\
\text { Dev }\end{array}$ \\
\hline $\begin{array}{l}\text { Sosialisasi } \\
\text { Perpajakan }\end{array}$ & 100 & 38 & 55 & 48 & 4,408 \\
\hline $\begin{array}{l}\text { Pengetahuan } \\
\text { Perpajakan }\end{array}$ & 100 & 30 & 43 & 37,76 & 2,91 \\
\hline $\begin{array}{ll}\text { Kepatuhan Wajib } \\
\text { Pajak }\end{array}$ & 100 & 46 & 66 & 58,48 & 4,698 \\
\hline
\end{tabular}

Sumber: Data primer diolah, 2017

Berdasarkan tabel 4.5 dapat diketahui bahwa sosialisasi perpajakan memiliki ratarata 48 dengan deviasi standar sebesar 4,408. Rata-rata pengetahuan perpajakan senilai 37,76 dengan deviasi standar 2,91. Selanjutnya, kepatuhan wajib pajak memiliki rata-rata senilai 58,48 dengan deviasi standar 4,698.

\section{Uji Kualitas Data}

\section{Uji Validitas Data dan Reliabilitas Data}

Berdasarkan hasil uji validitas dibuktikan bahwa semua butir pertanyaan dalam kuesioner dinyatakan valid. Hal ini karena $\mathrm{r}$ hitung > r tabel. Sedangkan uji reliabilitas menunjukkan bahwa semua variabel dinyatakan reliabel. Hal ini dibuktikan dengan nilai Cronbach Alpha yang lebih tinggi dari 0,600 .

\section{Uji Asumsi Klasik}

Pada penelitian ini berdasarkan pengujian yang telah dilakukan dapat dinyatakan data dalam penelitian ini sudah lolos dalam pengujian asumsi klasik yang diantaranya yaitu uji normalitas, uji multikolinearitas, dan uji heteroskedastisitas.

\begin{tabular}{|c|c|c|c|c|c|c|}
\hline \multicolumn{7}{|c|}{$\begin{array}{c}\text { Analisis Jalur (Path Analysis) } \\
\text { Tabel } 3 \text { Hasil Uji Statistik F } \\
\text { ANOVA }^{\mathrm{b}}\end{array}$} \\
\hline $\begin{array}{l}\text { Mod } \\
\text { el }\end{array}$ & & $\begin{array}{l}\text { Sum } \\
\text { of } \\
\text { Squar } \\
\text { es }\end{array}$ & $\begin{array}{l}D \\
f\end{array}$ & $\begin{array}{l}\text { Mean } \\
\text { Squa } \\
\text { re }\end{array}$ & $F$ & Sig. \\
\hline 1 & $\begin{array}{l}\text { Regress } \\
\text { ion }\end{array}$ & $\begin{array}{r}808,0 \\
09\end{array}$ & 2 & $\begin{array}{r}404,0 \\
04\end{array}$ & $\begin{array}{c}28, \\
46\end{array}$ & $\begin{array}{l}.00 \\
0 \mathrm{a}\end{array}$ \\
\hline & $\begin{array}{l}\text { Residua } \\
l\end{array}$ & $\begin{array}{r}1376, \\
951 \\
\end{array}$ & $\begin{array}{l}9 \\
7 \\
\end{array}$ & $\begin{array}{r}14,19 \\
5\end{array}$ & & \\
\hline & Total & $\begin{array}{r}2184, \\
96 \\
\end{array}$ & $\begin{array}{l}9 \\
9 \\
\end{array}$ & & & \\
\hline $\begin{array}{l}D \\
\mathrm{~S}\end{array}$ & $\begin{array}{l}\text { dictors: } \\
\text { getahuar } \\
\text { pendent } \\
\text { mber: dat }\end{array}$ & $\begin{array}{l}\text { Donstan } \\
\text { erpaja } \\
\text { priabel: } \\
\text { primer }\end{array}$ & $\begin{array}{l}\text { an } \\
\text { Kep } \\
\text { iol. }\end{array}$ & $\begin{array}{l}\text { ialisasi } \\
\text { tuhan } \\
2017\end{array}$ & & kan, \\
\hline
\end{tabular}

Tabel 4

Hasil Uji Parsial (Uji t) Substruktur 1

\begin{tabular}{|c|c|c|c|c|c|}
\hline \multirow[t]{2}{*}{ Model } & \multicolumn{2}{|c|}{$\begin{array}{l}\text { Unstandardi } \\
\text { zed } \\
\text { Coefficients }\end{array}$} & \multirow{2}{*}{\begin{tabular}{l} 
Standardi \\
zed \\
Coefficien \\
ts \\
\multicolumn{1}{c}{ Beta }
\end{tabular}} & \multirow{2}{*}{$T$} & \multirow[t]{2}{*}{ Sig. } \\
\hline & $B$ & $\begin{array}{l}\text { Std. } \\
\text { Err } \\
\text { or }\end{array}$ & & & \\
\hline (Consta & 15,5 & 2,29 & & 6,78 & 0,00 \\
\hline$n t)$ & 56 & 3 & & 6 & 0 \\
\hline $\begin{array}{l}\text { Sosialis } \\
\text { asi } \\
\text { Perpajak }\end{array}$ & $\begin{array}{c}0,46 \\
3\end{array}$ & $\begin{array}{c}0,04 \\
8\end{array}$ & 0,701 & $\begin{array}{c}9,72 \\
6\end{array}$ & $\begin{array}{c}0,00 \\
0\end{array}$ \\
\hline
\end{tabular}

a. Dependent Variabel: pengetahuan perpajakan Sumber: data primer diolah 2017

Tabel 5 Hasil Uji Parsial (Uji t) Substruktur 1

\begin{tabular}{|c|c|c|c|c|c|}
\hline \multicolumn{6}{|c|}{$\begin{array}{c}\text { Hasil Uji Parsial (Uji t) } \\
\text { Substruktur } 1 \\
\end{array}$} \\
\hline \multirow{2}{*}{ Model } & $\begin{array}{l}\text { Unstar } \\
\text { d Coe }\end{array}$ & $\begin{array}{l}\text { lardize } \\
\text { icients }\end{array}$ & $\begin{array}{l}\text { Standard } \\
\text { ized }\end{array}$ & \multirow{2}{*}{$T$} & \multirow{2}{*}{ Sig } \\
\hline & $B$ & $\begin{array}{l}\text { Std. } \\
\text { Error }\end{array}$ & Beta & & \\
\hline $\begin{array}{l}\text { (Constan } \\
\text { t) }\end{array}$ & $\begin{array}{r}32,80 \\
8 \\
\end{array}$ & 4,488 & & 7,31 & 0 \\
\hline $\begin{array}{l}\text { Sosialisa } \\
\text { si } \\
\text { Perpajak }\end{array}$ & 0,535 & 0,093 & 0,502 & $\begin{array}{r}5,74 \\
4\end{array}$ & 0 \\
\hline
\end{tabular}
a. Dependent Variabel: Kepatuhan Wajib Pajak Sumber: data primer diolah 2017 


\section{JURNAL NOMINAL / VOLUME VII NOMOR 1 / TAHUN 2018}

Tabel 6

Hasil Uji Parsial (Uji t)

Substruktur 2 wajib pajak melalui pengetahuan perpajakan.

Berdasarkan tabel 3, 4, 5 dan gambar

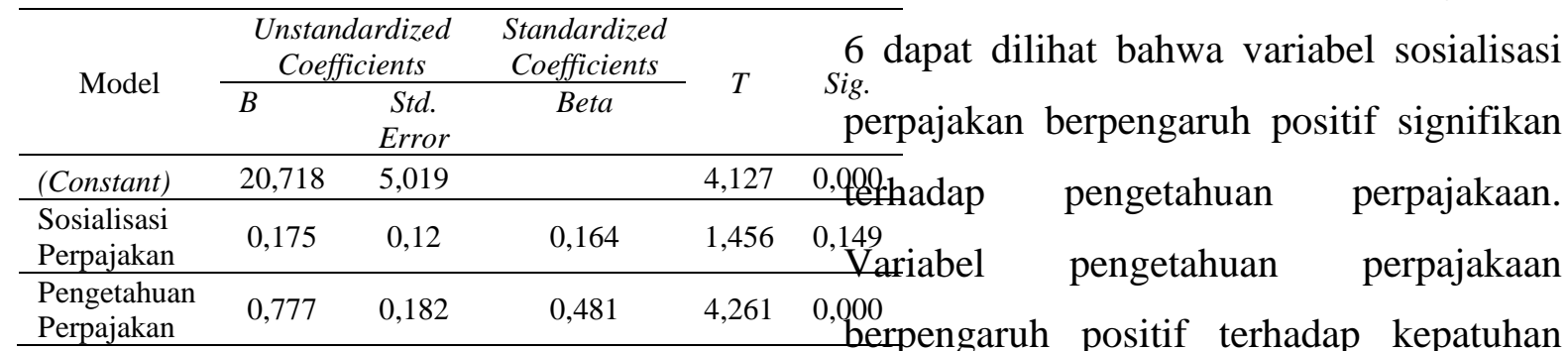

a. Dependent Variabel: Kepatuhan WP

Sumber: data primer diolah 2017

Analisis pengaruh sosialisasi perpajakan terhadap kepatuhan wajib pajak melalui pengetahuan perpajakan diketahui bahwa pengaruh langsung yang diberikan sosialisasi perpajakan terhadap kepatuhan wajib pajak secara langsung sebesar 0,502, sedangkan pengaruh tidak langsung sosialisasi perpajakan terhadap kepatuhan wajib pajak melalui pengetahuan perpajakan adalah perkalian antara nilai beta $\mathrm{X} 1$ terhadap $\mathrm{X} 2$ dengan nilai beta $\mathrm{X} 2$ terhadap Y yaitu, 0,701 x 0,597 =0,4185. Maka pengaruh total yang diberikan X2 terhadap $\mathrm{Y}$ adalah pengaruh langsung ditambah pengaruh tidak langsung yaitu, $0,502+0,4185=0,9205$. Berdasarkan hasil perhitungan diatas diperoleh nilai pengaruh langsung sosialisasi perpajakan terhadap kepatuhan wajib pajak sebesar 0,502 dan pengaruh tidak langsung sebesar 0,9205 yang berarti bahwa nilai pengaruh tidak langsung lebih besar dari nilai pengaruh langsung. Hasil ini menunjukan bahwa secara tidak langsung sosialisasi perpajakan berpengaruh signifikan terhadap kepatuhan wajib pajak. Variabel sosialisasi perpajkaan berpengaruh positif signifikan terhadap kepatuhan wajib pajak. Sosialisasi perpajakan berpengaruh positif signifikan terhadap kepatuhan wajib pajak melalui pengetahuan perpajakan. Hal ini dapat dilihat dengan membandingkan nilai thitung dan nilai t-tabel serta tingkat signifikanya berada dibawah 0,05 .

Apabila nilat t-hitung lebih besar dari nilai t-tabel maka $\mathrm{H} 1$ diterima dan $\mathrm{H} 0$ ditolak. sebaliknya jika nilai t-hitung lebih kecil dari nilai t-tabel maka H1 ditolak dan H0 diterima. Tabel 4.10, tabel 4.11, tabel, dan 4.12 menjelaskan sebagai berikut:

1) Variabel sosialisasi perpajakan memiliki nilai t-hitung 9,726 lebih besar dari nilai t-tabel 2,70 dengan nilai signifikan 0,000 . Hal ini menunjukan bahwa sosialisasi perpajakan berpengaruh signifikan terhadap pengetahuan perpajakan.

2) Variabel pengetahuan perpajakan memiliki nilai t-hitung 4,261 lebih besar dari nilai t-tabel 2,70 dengan nilai signifikan 0,000. Hal ini menunjukan 


\section{JURNAL NOMINAL / VOLUME VII NOMOR 1 / TAHUN 2018}

bahwa pengetahuan perpajakan berpengaruh signifikan terhadap kepatuhan wajib pajak.

3) Variabel sosialisasi perpajakan memiliki nilai t-hitung 5,744 lebih besar dari nilai t-tabel 2,70 dengan nilai signifikan 0,000. Hal ini menunjukan bahwa sosialisasi perpajakan berpengaruh positif signifikan terhadap kepatuhan wajib pajak.

4) Variabel sosialisasi perpajakan terhadap kepatuhan wajib pajak sebesar 0,502 dan pengaruh tidak langsung sebesar 0,4185. Hasil ini menunjukan bahwa secara tidak langsung sosialisasi perpajakan berpengaruh signifikan terhadap kepatuhan wajib pajak melalui pengetahuan perpajakan.

Tabel 7

Tabel 9

Hasil Uji Koefisien Determinasi $\left(\mathbf{R}^{\mathbf{2}}\right)$

\begin{tabular}{ccccc}
\hline Model & $R$ & $R$ Square & $\begin{array}{c}\text { Adjusted } \\
\text { R Square }\end{array}$ & $\begin{array}{c}\text { Std. Error } \\
\text { of the } \\
\text { Estimate }\end{array}$ \\
\hline 1 & \multicolumn{1}{c}{.597a } & 0,356 & 0,349 & 3,789 \\
\hline a. & $\begin{array}{l}\text { Predictors: } \\
\text { Perpajakan }\end{array}$ & (Constant),Pengetahuan \\
b. & $\begin{array}{l}\text { Dependent } \\
\text { pajak } \\
\end{array}$ & Variabel: & Kepatuhan & wajib \\
& Sumber: data primer diolah 2017
\end{tabular}

Tabel 10

Hasil Uji Koefisien Determinasi $\left(\mathbf{R}^{\mathbf{2}}\right)$

\begin{tabular}{|c|c|c|c|c|}
\hline Model & $R$ & $R$ Square & $\begin{array}{l}\text { Adjusted } \\
R \text { Square }\end{array}$ & $\begin{array}{c}\text { Std. Error } \\
\text { of the } \\
\text { Estimate }\end{array}$ \\
\hline 1 & $.608 a$ & 0,37 & 0,357 & 3,768 \\
\hline $\begin{array}{ll}\text { a. } & I \\
& \mathrm{~F} \\
\text { b. } & I\end{array}$ & $\begin{array}{l}\text { edictor: } \\
\text { pajaka } \\
\text { penden } \\
\text { mber: } \mathrm{c}\end{array}$ & $\begin{array}{l}\text { (Constant } \\
\text { Pengetah } \\
\text { Variabel: } \\
\text { ta primer }\end{array}$ & $\begin{array}{l}\text { Sosialisasi } \\
\text { n Perpajaka } \\
\text { epatuhan W } \\
\text { lah } 2017\end{array}$ & \\
\hline
\end{tabular}

Berdasarkan tabel 7, tabel 8, tabel 9 dan 10 di atas, dapat diketahui bahwa nilai adjusted $R$ Square sosialisasi perpajakan ke pengetahuan perpajakanadalah sebesar 0,491 atau $49,1 \%$. Hal ini menunjukan bahwa sosialisasi perpajakan mempengaruhi pengetahuan perpajakan Hasil Uji Koefisien Determinasi $\left(\mathbf{R}^{2}\right)$ \begin{tabular}{lllll}
\hline Model & $R$ & $R$ Square & Adjusted & Std. Error
\end{tabular} sebesar $49,1 \%$ dan sisanya $50,9 \%$ di $R$ Square of the pengaruhi oleh variabel lain di luar variabel

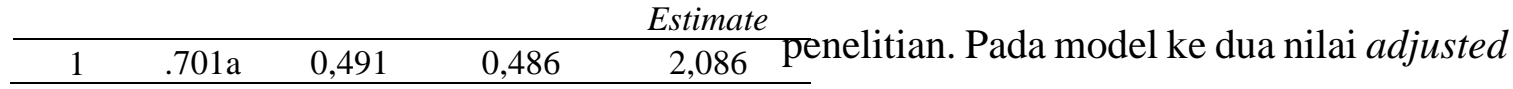

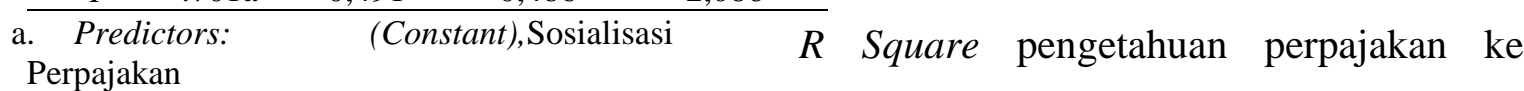
b. Dependent Variabel: Pengetahuan Perpajakan

Sumber: data primer diolah 2017

kepatuhan wajib pajak adalah sebesar 0,356

Tabel 8 atau 35,6\%. Hal ini menunjukkan bahwa Hasil Uji Koefisien Determinasi $\left(\mathbf{R}^{2}\right)$

\begin{tabular}{lccc}
\hline Model $R$ & $R$ Square $\begin{array}{c}\text { Adjusted } \\
R \text { Square }\end{array}$ & St \\
\hline $1 \quad .502 \mathrm{a}$ & 0,252 & 0,244 \\
\hline $\begin{array}{l}\text { Predictors: } \\
\text { Perpajakan }\end{array}$ & \multicolumn{1}{c}{ (Constant),Sosialisasi } \\
$\begin{array}{l}\text { Dependent } \\
\text { pajak } \\
\text { Sumber: data primer diolah } 2017\end{array}$
\end{tabular}

pengetahuan perpajakan mempengaruhi kepatuhan wajib pajak sebesar 35,6\%, of the sedangkan sisanya $64,4 \%$ dipengaruhi oleh Estimate 4,084 faktor lain di luar variabel penelitian.

\footnotetext{
a. Predictors: (Constant), Sosialisasi

Perpajakan pajak
}

Pada model ketiga nilai adjusted $R$

Square sosialisasi perpajakanke kepatuhan wajib pajak adalah sebesar 0,252 atau 25,2\%. Hal ini menujukan bahwa sosialisasi 


\section{JURNAL NOMINAL / VOLUME VII NOMOR 1 / TAHUN 2018}

perpajakan mempengaruhi kepatuhan wajib pajak sebesar $25,2 \%$, sedangkan sisanya $74,8 \%$ dipengaruhi oleh variabel lain. Pada model keempat nilai adjusted $R$ Square sosialisasi perpajakanke kepatuhan wajib pajak melalui pengetahuan perpajakan adalah sebesar 0,37 atau $37 \%$. Hal ini menunjukan sosialisasi perpajakan mempengaruhi kepatuhan wajib pajak melalui pengetahuan perpajakan sebesar $37 \%$ dan sisanya sebesar $63 \%$ dipengarui oleh variabel lain.

\section{PEMBAHASAN}

\section{Pengaruh Sosialisasi Perpajakan}

\section{Terhadap Pengetahuan Perpajakan}

Hipotesis 1 yang diajukan dalam penelitian ini adalah sosialisasi perpajakan berpengaruh positif terhadap pengetahuan perpajakan. Berdasarkan hasil nilai t-hitung 9,726 lebih besar dari nilai t-tabel 2,70 dengan nilai signifikan 0,000 , maka $\mathrm{H} 1$ terdukung dan $\mathrm{H} 0$ ditolak, yang berarti bahwa sosialisasi perpajakan berpengaruh positif signifikan terhadap pengetahuan perpajakan. Hal ini menunjukan bahwa variabel sosialisasi perpajakan yang diberikan sudah baik karena dapat menambah pengetahuan wajib pajak untuk melakukan pembayaran perpajakan. Sehingga dapat diartikan apabila semakin tinggi tingkat intensitas sosialisasi yang dilakukan oleh KPP Pratama Kebumen, maka akan semakin tinggi pula tingkat pengetahuan perpajakan wajib pajak. Karena dengan adanya sosialisasi, wajib pajak akan lebih mengetahui, memahami dan menyadari mengenai peraturan dan tata cara perpajakan, yang membuat wajib pajak dapat melaksanakan kewajiban perpajakannya dengan patuh, sehingga sosialisasi perpajakan berpengaruh positif terhadap pengetahuan perpajakan.

Hasil penelitian ini mendukung penelitian yang dilakukan Jannah (2016:46) menemukan sosialisasi pajak yang intensif dapat meningkatkan pengetahuan calon wajib pajak mengenai semua hal yang berkaitan dengan perpajakan. Penelitian Anwar (2015:53) menyatakan sosialisasi perpajakan berpengaruh signifikan terhadap pengetahuan perpajakan wajib pajak. Berbeda dengan penelitian Winerungan (2013: 967) bahwa dengan kurang intensifnya sosialisasi yang diberikan akan berdampak pada rendahnya pengetahuan dan pemahaman wajib pajak sehingga berpengaruh pada kepatuhan pajaknya.

\section{Pengaruh Pengetahuan Perpajakan} Terhadap Kepatuhan Wajib Pajak

Hipotesis 2 yang diajukan dalam penelitian ini adalah pengetahuan perpajakan berpengaruh positif terhadap kepatuhan wajib pajak. Hasil uji hipotesis 2 menyimpulkan bahwa pengetahuan perpajakan berpengaruh positif signifikan terhadap kepatuhan wajib pajak. Hal ini dibuktikan dengan hasil nilai t-hitung 4,261 


\section{JURNAL NOMINAL / VOLUME VII NOMOR 1 / TAHUN 2018}

lebih besar dari nilai t-tabel 2,70 dengan nilai signifikan 0,000. Berdasarkan hasil tersebut, maka $\mathrm{H} 2$ terdukung dan $\mathrm{H} 0$ ditolak.

Hal tersebut karena hasil penelitian ini menunjukan bahwa pengetahuan perpajakan yang diterima oleh wajib pajak dapat menjamin wajib pajak untuk mematuhi kewajiban membayar pajaknya. Jika wajib pajak memiliki tingkat pengetahuan yang tinggi tentang perpajakan, maka kepatuhan kewajiban pajaknya akan meningkat sehingga tercapai target pendapatan pajak yang nantinya dapat digunakan untuk kegiatan operasional dan pembangunan suatu negara, sehingga pengetahuan perpajakan berpengaruh positif terhadap kepatuhan wajib pajak. Hasil penelitian ini mendukung penelitian yang dilakukan oleh Witono (2008:206) yang menyatakan terdapat pengaruh yang signifikan pengetahuan pajak terhadap tingkat kepatuhan wajib pajak dan penelitian Tambun (2016:36) yang menyatakan bahwa pengetahuan wajib pajak berpengaruh signifikan terhadap kepatuhan wajib pajak. Berbeda dengan penelitian Hardiningsih dkk (2011:138) yang menyatakan pengetahuan peraturan perpajakan tidak berpengaruh terhadap kemauan membayar pajak.

\section{Pengaruh Sosialisasi Perpajakan}

\section{Terhadap Kepatuhan Wajib Pajak}

Hipotesis 3 yang diajukan dalam penelitian ini adalah sosialisasi perpajakan berpengaruh positif terhadap kepatuhan wajib pajak. Hasil uji hipotesis 3 menyimpulkan bahwa sosialisasi perpajakan berpengaruh signifikan terhadap kepatuhan wajib pajak. Hal ini dibuktikan dengan hasil nilai t-hitung 5,744 lebih besar dari nilai t-tabel 2,70dengan nilai signifikan 0,000. Berdasarkan hasil tersebut, maka H3 diterima dan $\mathrm{H} 0$ ditolak.

Hal tersebut karena hasil penelitian ini menunjukan bahwa sosialisasi perpajakan merupakan hal penting yang harus selalu ditingkatkan oleh KPP Pratama Kebumen, karena sosialisasi perpajakan mampu menyampaikanan informasi mengenai perpajakan kepada wajib pajak sehingga dapat mempengaruhi kepatuhan wajib pajak dalam memenuhi kewajiban perpajakannya sehingga akan meningkatkan kepatuhan wajib pajak. Sesuai dengan teori yang dikemukakan oleh Puspita (2016:3), dengan dilakukannya sosialisasi tentang pajak, diharapkan dapat membuat wajib pajak mengetahui, memahami, dan menyadari pentingnya pajak bagi pembangunan. Dengan demikian, wajib pajak merespon diadakannya sosialisasi perpajakan yang diberikan. Kehadiran wajib pajak dalam mengikuti sosialisasi perpajakan, 


\section{JURNAL NOMINAL / VOLUME VII NOMOR 1 / TAHUN 2018}

menyebabkan wajib pajak mengetahui, memahami, dan menyadari pentingnya pajak bagi pembangunan, sehingga wajib pajak lebih patuh dalam melaksanakan kewajiban perpajakan. Hal ini menyebabkan sosialisasi perpajakan berpengaruh terhadap kepatuhan wajib pajak.

Hal ini didukung oleh penelitian Rohmawati dkk (2012:12) yang menyatakan sosialisasi berpengaruh positif terhadap kepatuhan Wajib Pajak dan Purba (2016:29) yang menyatakan bahwa terdapat pengaruh positif antara sosialisasi perpajakan terhadap kepatuhan wajib pajak orang pribadi. Berbeda dengan penelitian Winerungan (2013:969) yang menyatakan sosialisasi perpajakan tidak memiliki pengaruh terhadap kepatuhan wajib pajak orang.

\section{Pengaruh Sosialisasi Perpajakan}

Terhadap Kepatuhan Wajib Pajak dengan Pengetahuan Perpajakan Sebagai Variabel Intervening

Hipotesis 4 yang diajukan dalam penelitian ini adalah sosialisasi perpajakan berpengaruh terhadap kepatuhan wajib pajak melalui pengetahuan perpajakan. Hasil uji hipotesis 4 menyimpulkan bahwa sosialisasi perpajakan berpengaruh signifikan terhadap kepatuhan wajib pajak melalui pengetahuan perpajakan. Hal ini dibuktikan dengan hasil perhitungan diatas, bahwa nilai pengaruh langsung sosialisasi perpajakan terhadap kepatuhan wajib pajak sebesar 0,502 dan pengaruh tidak langsung sebesar 0,9205 yang berarti bahwa nilai pengaruh tidak langsung lebih besar dari nilai pengaruh langsung, hasil ini menunjukan bahwa secara tidak langsung sosialisasi perpajakan berpengaruh signifikan terhadap kepatuhan wajib pajak melalui pengetahuan perpajakan. Apabila sosialisasi perpajakan dapat menambah pengetahuan wajib pajak dalam melakukan pembayaran pajak maka wajib pajak merasa puas dengan sosialisasi perpajakan yang diberikan. Pengetahuan perpajakan yang didapatkan wajib pajak akan berdampak pada tingkat kepatuhan wajib pajak, karena jika wajib pajak mengetahui tata cara pembayaran pajak maka wajib pajak akan mau memenuhi kewajibanya untuk membayar pajak. Pengetahuan perpajakan berpengaruh positif terhadap kepatuhan wajib pajak, karena semakin tinggi pengetahuan dan pemahaman wajib pajak maka wajib pajak dapat menentukan perilakunya dengan lebih baik dan sesuai dengan ketentuan perpajakan, yaitu menjadi lebih patuh (Rohmawati dkk, 2012:12).

Hasil penelitian ini mendukung penelitian Anwar (2015:53) menemukan sosialisasi perpajakan berpengaruh signifikan terhadap pengetahuan perpajakan wajib pajak. Penelitian Purba (2016:29) menemukan bahwa terdapat pengaruh positif antara sosialisasi 


\section{JURNAL NOMINAL / VOLUME VII NOMOR 1 / TAHUN 2018}

perpajakan terhadap kepatuhan wajib pajak orang pribadi. Penelitian Witono (2008:206) menyatakan terdapat pengaruh yang signifikan pengetahuan pajak terhadap tingkat kepatuhan wajib pajak.

\section{KESIMPULAN}

Berdasarkan hasil penelitian yang dilakukan dapat disimpulkan bahwa:

a. Sosialisasi perpajakan berpengaruh positif terhadap pengetahuan perpajakan.

b. Pengetahuan perpajakan berpengaruh positif terhadap kepatuhan wajib pajak.

c. Sosialisasi perpajakan berpengaruh positif terhadap kepatuhan wajib pajak.

d. Sosialisasi perpajakaan berpengaruh positif terhadap kepatuhan wajib pajak melalui pengetahuan perpajakan.

\section{KETERBATASAN PENELITIAN}

Penelitian ini tidak lepas dari keterbatasan dan diharapkan dapat dijadikan sumber ide bagi penelitian selanjutnya. Beberapa keterbatasan dalam penelitian ini diantaranya yang pertama adalah hasil penelitian ini hanya berdasarkan jawaban dari responden terhadap kuesioner yang dibagikan, serta tidak didukung dengan wawancara. Kedua, dalam pengisian kuesioner ada kemungkinan jawaban tersebut tidak sesuai dengan keadaan sebenarnya. Hal ini bisa terjadi ketika responden tidak fokus saat menjawab kuesioner, karena terdapat beberapa responden pada saat mengisi kuesioner sedang melakukan aktivitas lain secara bersamaan dan ada juga yang terburu-buru saat mengisi kuesioner. Keterbatasan terahir yaitu penelitian ini hanya menggunakan tiga variabel yaitu, sosialisasi perpajakan, pengetahuan perpajakan dan kepatuhan wajib pajak.

\section{SARAN}

\section{Bagi Pihak KPP Pratama Kebumen}

Berdasarkan hasil pengujian yang dilakukan terhadap masing-masing variabel terdapat hasil yang ditunjukan oleh responden bahwa sosialisasi perpajakan berpengaruh terhadap kepatuhan wajib pajak. Tindakan yang dapat dilakukan oleh pihak KPP Pratama Kebumen untuk lebih meningkatkan kepatuhan wajib pajak adalah dengan memperluas sosialisasi perpajakan kepada wajib pajak agar wajib pajak lebih paham terhadap hak dan kewajiban perpajakannya.

\section{Bagi Penelitian Selanjutnya}

Berdasarkan kesimpulan dan keterbatasan dari hasil penelitian ini, saran yang dapat diberikan bagi peneliti selanjutnya adalah penelitian selanjutnya dapat mengganti model penelitian ini dengan mengubah variabel intervening menjadi variabel lain. Model penelitian ini juga dapat dikembangkan dengan menambah variabel lain diluar penelitian ini yang dapat mempengaruhi kepatuhan wajib 


\section{JURNAL NOMINAL / VOLUME VII NOMOR 1 / TAHUN 2018}

pajak seperti ketegasan sanksi perpajakan dan kualitas pelayanan perpajakan. Penelitian selanjutnya dapat menambahkan metode lain, seperti menggunakan model wawancara.

\section{DAFTAR PUSTAKA}

Anwar, Rizki Akbar. 2015. "Pengaruh Sosialisasi Perpajakan Terhadap Kepatuhan Perpajkaan Wajib Pajak Usaha Mikro Kecil dan Menengah (UMKM) di Surakarta dengan Pengetahuan Perpajakan sebagai Variabel Pemediasi”. Skripsi,Program Studi Akuntani Fakultas Ekonomi dan Bisnis Universitas Sebela Maret Surakarta.

Anonim. "Data Penerimaan". http://www.sumeks.co.id. Diakses pada tanggal 10 Maret 2017 pukul 12:09 WIB.

Fahlevi, Muhammad Reza. 2017. "Pengaruh Akuntabilitas, Gender, dan Pengalaman Kerja Audit Terhadap Kualitas Hasil Kerja Auditor Dengan Pengetahuan sebagai Variabel Moderasi”. JOM Fekon, Vol.4, No.1, Februari 2017.

Fatimah, Siti \& Wardani, Dewi Kusuma. 2017. "Faktor-faktor Yang Mempengaruhi Penggelapan Pajak Di Kantor Pelayanan Pajak Pratama Temanggung". Akuntansi Dewantara, Vol. 1, No.4. p-ISSN: 2550-0376, eISSN: 2549-9637.

Ghozali, Imam. 2011. Aplikasi Analisis Multivariate dengan Program SPSS.Semarang : BP Undip.

Hardiningsih, Pancawati dan Yulianawati, Nila. 2011. "Faktor-Faktor yang Mempengaruhi Kemauan Membayar Pajak“. Dinamika Keuangan dan
Perbankan, Vol. 3, No.1, November 2011.

Jannah, Shofuro Zahrotul. 2016. "Pengaruh Pengetahuan, Penghasilan, Manfaat Atas NPWP, Sanksi, dan Sosialisasi Terhadap Kepatuhan Pemilik UMKM dalam Memiliki NPWP (Studi Di KPP Pratama Surakarta)“. Skripsi, Jurusan Akuntansi Syariah Fakultas Ekonomi dan Bisnis IslamInstitut Agama Islam Negeri Surakarta. Jurusan Pendidikan Akuntansi Fakultas Ekonomi Universitas Negeri Yogyakarta.

Khasanah, Septiyani Nur. 2014. "Pengaruh Pengetahuan Perpajakan, Modernisasi Sistem Administrasi Perpajakan, dan Kesadaran Wajib Pajak Terhadap Kepatuhan Wajib Pajak Pada Kantor Wilayah Direktorat Jenderal PajakDaerah Istimewa YogyakartaTahun 2013". Skripsi, Program Studi Akuntansi Jurusan Pendidikan Akuntansi Fakultas Ekonomi Universitas Negeri Yogyakarta.

Kuncoro, Mudrajad. 2003. "Metode Riset Untuk Bisnis dan Ekonomi “. Jakarta: Erlangga

Mardiasmo. 2009. "Perpajakan". Yogyakarta: Andi

Mulyadi. 2008. "Sistem Akuntansi". Jakarta: Salemba Empat

Nurhidayah, Sari. 2015. "Pengaruh Penerapan Sistem E-Filling Terhadap Kepatuhan Wajib Pajak DenganPemahaman Internet Sebagai Variabel Pemoderasi pada KPP Pratama Klaten". Skripsi, Program Studi Akuntansi.

Prabowo, Agung Dwi. 2015. "Efektivitas Sosialisasi Perpajakan Terhadap Kepatuhan Pelaporan SPT Tahunan 


\section{JURNAL NOMINAL / VOLUME VII NOMOR 1 / TAHUN 2018}

Wajib Pajak Orang Pribadi pada Kantor Pelayanan, Penyuluhan, dan Konsultasi Perpajakan (KP2KP) Tondano“. Jurnal EMBA, Vol. 3, No. 1, Maret 2015.

Primasari, Nora Hilmia. 2016. "FaktorFaktor yang Mempengaruhi Kepatuhan Wajib Pajak Orang Pribadi yang Melakukan Pekerjaan Bebas “. Jurnal Akuntansi dan Keuangan, Vol.5, No.2, Oktober 2016.

Purba, Biatar Pandapotan. 2016. "Pengaruh Sosialisasi Perpajakan dan Pemahaman Perpajakan Terhadap Kepatuhan Wajib Pajak Orang Pribadi Dengan Pelayanan Fiskus Sebagai Variabel Moderating di Kantor Pelayanan Pajak Jakarta Kembangan". Jurnal media Akuntansi Perpajakan, Vol.1, No.2, Jul-Des 2016: 29-43.

Puspita, Erna. 2016. "Analisis Jalur Pengaruh Sosialisasi Terhadap Kepatuhan Wajib Pajak Bumi Dan Bangunan Kota Kediri Dengan Kesadaran Sebagai Variabel Intervening“. Jurnal Akuntansi dan Ekonomi, Vol.1 No.1, September 2016.

Rahayu, Nurulita. 2017. “ Pengaruh Pengetahuan Perpajakan, Ketegasan Sanksi Pajak, dan Tax Amnesty terhadap Kepatuhan Wajib Pajak". Akuntansi Dewantara, Vol. 1, No., April 2017. p-ISSN: 2550-0376, eISSN: 2549-9637.

Rohmawati, Lusia. Prasetyono dan Yuni Rimawati. 2012.“ Pengaruh Sosialisasi dan Pengetahuan Perpajakan Terhadap Tingkat Kesadaran dan Kepatuhan Wajib Pajak (Studi pada Wajib Pajak Orang Pribadi yang Melakukan Kegiatan Usaha dan Pekerjaan Bebas pada KPP Pratama Gresik Utara)“. Proiding Simposium Nasional Perpajakan 4.
Sekaran, Uma. 2006."Research Methods for Business : Metodologi Penelitian untuk Bisnis". Edisi 4. Jakarta : Salemba Empat

Setiawan, Aditya. 2016. "Peranan KPP Pratama Dalam Meningkatkan Jumlah Wajib Pajak Di Kabupaten Kebumen". Skripsi. Fakultas Hukum Universitas Muhammadiyah Yogyakarta.

Sudrajat, Ajat, dan Arles Parulian Ompusunggu. 2015. "Pemanfaatan Teknologi Informasi, Sosialisasi Pajak, Pengetahuan Perpajakan, dan Kepatuhan Pajak“. Jurnal Riset Akuntansi dan Perpajakan JRAP, Vol. 2, No. 2, Desember 2015.

Susanto, Jessica Novia. 2013. "Pengaruh Persepsi Pelayanan Pajak, Persepsi Pengetahuan Wajib Pajak, dan Persepsi Pengetahuan Korupsi Terhadap Kepatuhan“. Jurnal Ilmiah Mahasiswa Universitas Surabaya, Vol.2, No.1.

Suyanto, Pasca Putri Lopian Ayu Intansari dan Supeni Endahjati. 2016. "Tax Amnesti“. Jurnal Akuntansi, Vol.4, No.2, Desember 2016.

Tambun, Sihar. 2016. "Anteseden Kepatuhan Wajib Pajak Orang Pribadi dan Moderasi Sosialisasi Perpajakan“. Jurnal Media Akuntansi Perpajakan, Vol.1, No.1.

Undang-Undang Nomor 16 tahun 2009 KUP tentang definisi pajak.

Wardani, Dewi Kusuma \& Asis, Moh. Rifqi. 2017. "Pengaruh Pengetahuan Wajib Pajak, Kesadaran Wajib Pajak, dan Program Samsat Corner terhadap Kepatuhan Wajib Pajak Kendaraan Bermotor". Akuntansi Dewantara. Vol. 1. No. 2, Oktober 2017. p-ISSN: 2550-0376. e-ISSN: 2549-9637 
Widowati, Rizky. 2015. "Kepatuhan Wajib Pajak Melalui Sosialisasi Perpajakan, Sanksi Perpajakan, Pengetahuan Pajak dan Pelayanan Fiskus".

Winerungan, Oktaviane Lidya. 2013. "Sosialisasi Perpajakan, Pelayanan Fiskus dan Sanksi Perpajakan Terhadap Kepatuhan WPOP di KPP Manado dan KPP Bitung“.Jurnal EMBA, Vol.1 No.3, September 2013.

Witono, Banu. 2008. "Peranan Pengetahuan Pajak pada Kepatuhan Wajib Pajak". Jurnal Akuntansi dan Keuangan, Vol.7, No. 2, September 2008.

Wulandari, Tika, dan Suyanto. 2014. "Pengaruh Pengetahuan Perpajakan, Tingkat Pendidikan, dan Sanksi Administrasi Terhadap Kepatuhan Wajib Pajak Dalam Melakukan Pembayaran Pajak Bumi Bangunan“. Jurnal Akuntansi, Vol.2, No.2, Desember 2014.

Wurianti , Exti Lusiani Ega. 2015. “Analisis Faktor - Faktor Yang Mempengaruhi Kepatuhan Wajib Pajak di Wilayah KPP Pratama”. Jurnal Ilmu dan Riset Akuntansi, Vol.4, No.6. 